\title{
Chromium (VI) in phosphorus fertilizers determined with the diffusive gradients in thin-films (DGT) technique
}

\author{
Christian Vogel ${ }^{1}$ - Marie C. Hoffmann ${ }^{1}$ - Oliver Krüger ${ }^{2}$ - Vadim Murzin ${ }^{3,4}$. \\ Wolfgang Caliebe $^{3}$. Christian Adam ${ }^{1}$
}

Received: 3 February 2020 / Accepted: 3 April 2020 / Published online: 18 April 2020

(C) The Author(s) 2020

\begin{abstract}
Phosphorus (P) fertilizers from secondary resources became increasingly important in the last years. However, these novel P-fertilizers can also contain toxic pollutants such as chromium in its hexavalent state $(\mathrm{Cr}(\mathrm{VI}))$. This hazardous form of chromium is therefore regulated with low limit values for agricultural products even though the correct determination of $\mathrm{Cr}(\mathrm{VI})$ in these fertilizers may be hampered by redox processes, leading to false results. Thus, we applied the novel diffusive gradients in thin-films (DGT) technique for $\mathrm{Cr}(\mathrm{VI})$ in fertilizers and compared the results with the standard wet chemical extraction method (German norm DIN EN 15192) and Cr K-edge X-ray absorption near-edge structure (XANES) spectroscopy. We determined an overall good correlation between the wet chemical extraction and the DGT method. DGT was very sensitive and for most tested materials selective for the analysis of $\mathrm{Cr}(\mathrm{VI})$ in P-fertilizers. However, hardly soluble $\mathrm{Cr}(\mathrm{VI})$ compounds cannot be detected with the DGT method since only mobile $\mathrm{Cr}(\mathrm{VI})$ is analyzed. Furthermore, Cr K-edge XANES spectroscopy showed that the DGT binding layer also adsorbs small amounts of mobile $\mathrm{Cr}(\mathrm{III})$ so that $\mathrm{Cr}(\mathrm{VI})$ values are overestimated. Since certain types of the Pfertilizers contain mobile $\mathrm{Cr}(\mathrm{III})$ or partly immobile $\mathrm{Cr}(\mathrm{VI})$, it is necessary to optimize the DGT binding layers to avoid aforementioned over- or underestimation. Furthermore, our investigations showed that the Cr K-edge XANES spectroscopy technique is unsuitable to determine small amounts of $\operatorname{Cr}(\mathrm{VI})$ in fertilizers (below approx. $1 \%$ of $\mathrm{Cr}(\mathrm{VI})$ in relation to total $\mathrm{Cr}$ ).
\end{abstract}

Keywords Phosphorus recovery $\cdot$ Sewage sludge ash $\cdot$ Hexavalent chromium $(\mathrm{Cr}(\mathrm{VI})) \cdot$ Chemical extraction $\cdot$ X-ray adsorption near-edge structure (XANES) spectroscopy

Responsible Editor: Philippe Garrigues

Electronic supplementary material The online version of this article (https://doi.org/10.1007/s11356-020-08761-w) contains supplementary material, which is available to authorized users.

Christian Vogel

christian.vogel@bam.de

1 Bundesanstalt für Materialforschung und -prüfung (BAM), Unter den Eichen 87, 12205 Berlin, Germany

2 Department of Chemical and Product Safety, Bundesinstitut für Risikobewertung (BfR), Max-Dohrn-Str. 8-10, 10589 Berlin, Germany

3 DESY, Notkestrasse 85, 22603 Hamburg, Germany

4 Bergische Universität Wuppertal, Gaußstraße 20, 42119 Wuppertal, Germany

\section{Introduction}

Phosphorus (P) is essential for all living beings and is supplied by their respective nutrition. It is removed from farmlands in the form of agricultural products and must be replaced by application of fertilizers to allow continuous farming. Since phosphate rock and $\mathrm{P}$ became a scarce resource in the European Union (EU 2017), several processes are under development to recover $\mathrm{P}$ from wastewater for fertilizer production (Schaum 2018; Kratz et al. 2019). However, these novel P-fertilizers can also contain pollutants that are toxic for plants, animals, and humans.

One potential pollutant in P-fertilizers is chromium $(\mathrm{Cr})$ in the hexavalent oxidation state $(\mathrm{Cr}(\mathrm{VI}))$ also called chromate $\left(\mathrm{CrO}_{4}{ }^{2-}\right)$ or dichromate $\left(\mathrm{Cr}_{2} \mathrm{O}_{7}{ }^{2-}\right)$. In contrast to the trivalent form $\mathrm{Cr}(\mathrm{III})$, which is an essential trace element, $\mathrm{Cr}(\mathrm{VI})$ is a highly mobile, toxic, and carcinogenic compound (Shahid 
et al. 2017). Therefore, the German fertilizer ordinance (2012) has a strict limit of $2 \mathrm{mg} \mathrm{kg}^{-1} \mathrm{Cr}(\mathrm{VI})$ in fertilizers. Previous research (Krüger et al. 2017) revealed that various kinds of common and novel fertilizers can contain $\mathrm{Cr}(\mathrm{VI})$. An established chemical extraction method for the determination of $\mathrm{Cr}(\mathrm{VI})$ is the German standard DIN EN ISO 15192. In this method, an alkaline media is used at temperatures above $90{ }^{\circ} \mathrm{C}$ to extract $\mathrm{Cr}(\mathrm{VI})$ and subsequently determine its concentration. However, the use of elevated temperatures and high $\mathrm{pH}$ values may hamper the correct determination of $\mathrm{Cr}(\mathrm{VI})$ concentrations especially in organic- and/or Fe(II)-rich matrices. The organic matter and $\mathrm{Fe}(\mathrm{II})$ in these matrices can reduce $\mathrm{Cr}(\mathrm{VI})$ and therefore cause misleading results. To overcome this problem, this study applied the novel diffusive gradients in thin-films (DGT) technique where water is used to extract the $\mathrm{Cr}(\mathrm{VI})$ from the solid material at ambient temperature. Consequently, the transformation of $\mathrm{Cr}$ species by high $\mathrm{pH}$ values at high temperatures is avoided by the DGT method. The DGT approach was subsequently compared with the aforementioned standard extraction method and observations made with $\mathrm{Cr} \mathrm{K}$-edge X-ray absorption near-edge structure (XANES) spectroscopy.

Previous DGT studies showed that the amount of nutrients and pollutants adsorbed by the binding layer of the DGT method nicely correlates to their bioavailability (Davison 2016; Vogel et al. 2017). The DGT device consists of a binding layer, a diffusion gel, and a filter (to protect the gel) assembled in a plastic holder (Davison 2016). The dissolved and labile $\mathrm{Cr}(\mathrm{VI})$ fraction of the fertilizer from moist fertilizer samples diffuses through the filter and the diffusion gel. During deployment, it subsequently adsorbs on a $\mathrm{Cr}(\mathrm{VI})$ selective binding layer (Pan et al. 2015). However, small amounts of $\mathrm{Cr}$ (III) may also adsorb to that binding layer. Hence, to evaluate the $\mathrm{Cr}(\mathrm{VI})$ selectivity of the DGT method, we applied Cr K-edge XANES spectroscopy because this approach enables a clear differentiation between the two oxidation states. In fact, a compound containing $\mathrm{Cr}(\mathrm{VI})$ will exhibit a prominent pre-peak within the XANES spectra, whereas compounds without any hexavalent $\mathrm{Cr}$ will not show this feature (Vogel et al. 2014, 2015a.

\section{Materials and methods}

\section{Fertilizers origin and treatment}

To provide samples with a variety of different $\mathrm{Cr}(\mathrm{VI})$ mass fractions, a recycling P-fertilizer was chosen as a model substance for this investigation. The recycling P-fertilizers are produced from sewage sludge ashes by thermochemical treatment with a sodium additive to produce the bioavailable phosphate form $\mathrm{CaNaPO}_{4}$ (Stemann et al. 2015; Herzel et al. 2016). In contrast to the real thermochemical process, which is generally operated under reducing conditions, the samples here were prepared under oxidizing conditions to trigger $\mathrm{Cr}(\mathrm{VI})$ formation. The SSA originated from industrial-fluidized bed incinerators in Germany, where sewage sludge from municipal wastewater treatment plants was incinerated solely. This SSA was thermochemically treated with different amounts of $\mathrm{Na}_{2} \mathrm{CO}_{3}$ to prepare the $\mathrm{Cr}(\mathrm{VI})$ containing model substances for the investigation. Therefore, $40 \mathrm{~g}$ of SSA was mixed with $1 \mathrm{~g}$ (SSA-Na1), $4 \mathrm{~g}$ (SSA-Na2), $7 \mathrm{~g}$ (SSANa3), 10 g (SSA-Na4), 11 g (SSA-Na5; similar to Pfertilizer in Vogel et al. 2014 and Krüger et al. 2017), and $20 \mathrm{~g}$ (SSA-Na6) of $\mathrm{Na}_{2} \mathrm{CO}_{3}$ (Fisher Chemicals Loughborough, UK), respectively. Afterwards, it was thermochemically treated at $950{ }^{\circ} \mathrm{C}$ for $30 \mathrm{~min}$, under oxidizing conditions (air) in a muffle furnace (Nabertherm LH 15/14, Lillenthal, Germany).

Furthermore, a sedimentary phosphate rock (PR) from Morocco, a triple super phosphate (TSP) and a converter lime (CL) were used as potentially $\mathrm{Cr}(\mathrm{VI})$ bearing fertilizers for the investigation.

All fertilizer samples were air-dried, divided representatively by a dividing cross, and grinded with a tungsten carbide vibratory disc mill (see also Krüger et al. 2017). The total $\mathrm{Cr}$ amount of the fertilizers was measured by ICP-OES (Thermo iCAP 7000 Series, Dreieich, Germany) after total digestion $\left(\mathrm{HNO}_{3} / \mathrm{HClO}_{4} / \mathrm{HF}\right)$ in a microwave (mikroPrepA, MLS $\mathrm{GmbH}$, Leutkirch, Germany; heating with $1000 \mathrm{~W} ; 20 \mathrm{~min}$ isotherm segment at $240{ }^{\circ} \mathrm{C}$ ). These measurements were carried out in triplicate.

\section{Wet chemical chromium(VI) extraction (DIN method)}

We performed $\mathrm{Cr}(\mathrm{VI})$ wet chemical extraction according to DIN EN 15192 (2006). The procedure consists of an alkaline extraction of the solid sample, followed by filtration for liquid-solid separation and measurement of Cr(VI) by ICP-MS (Thermo iCAP Q, Dreieich, Germany). Therefore, $2.5 \mathrm{~g}$ of the sample (weighed in on $0.1 \mathrm{mg}$ ) were put in a $250 \mathrm{~mL}$ beaker, and the following chemicals were added: $50 \mathrm{~mL}$ of the extraction solution containing $0.5 \mathrm{~mol} \mathrm{~L}^{-1} \mathrm{NaOH}$ and $0.28 \mathrm{~mol} \mathrm{~L}^{-1}$ $\mathrm{Na}_{2} \mathrm{CO}_{3}$ (Fisher Chemicals Loughborough, UK), $1 \mathrm{~mL}$ of $4.2 \mathrm{~mol} \mathrm{~L}^{-1} \mathrm{MgCl}_{2} \cdot 6 \mathrm{H}_{2} \mathrm{O}$ (Merck, Darmstadt, Germany) to avoid $\mathrm{Cr}(\mathrm{III})$ oxidation by oxygen, and a buffer solution of each $0.5 \mathrm{~mol} \mathrm{~L}^{-1} \mathrm{~K}_{2} \mathrm{HPO}_{4}$ and $\mathrm{KH}_{2} \mathrm{PO}_{4}$ (both Carl Roth, Karlsruhe, Germany). We capped the beaker with a watch glass and heated the solution for $1 \mathrm{~h}$ at $92.5{ }^{\circ} \mathrm{C}$ on a magnetic hot plate stirrer with a PTFE-coated magnetic stir bar. The temperature was controlled with a contact thermometer to avoid boiling of the solution as well as evaporation to dryness. The measurements were carried out in triplicate. 


\section{Chromium(VI) DGT extraction}

The content of mobile $\mathrm{Cr}(\mathrm{VI})$ in the various fertilizers was also analyzed by DGT devices (window size, $2.54 \mathrm{~cm}^{2}$ ) equipped with a $0.8 \mathrm{~mm}$ APA (polyacrylamide) diffusion layer and a $0.6 \mathrm{~mm} \mathrm{Cr}(\mathrm{VI})$ selective N-methyl-D-glucamine (NMDG) binding layer (Pan et al. 2015; purchased from DGT Research, Lancaster, UK). After a $24 \mathrm{~h}$ conditioning period of the fertilizer at $60 \%$ of the water holding capacity (WHC; ISO 2012), the fertilizers were brought to $100 \%$ WHC, transferred onto the DGT devices, and deployed for $24 \mathrm{~h}$ at $25^{\circ} \mathrm{C}$. Subsequently, the extraction of adsorbed $\mathrm{Cr}$ from the DGT binding layer was carried out with $1 \mathrm{M}$ $\mathrm{HNO}_{3}$ for $24 \mathrm{~h}$. Afterwards, the $\mathrm{Cr}$ concentrations of the extracts were analyzed by ICP-MS (Thermo iCAP Q, Dreieich, Germany) and used to calculate the DGT values. The $\mathrm{C}_{\mathrm{DGT}}$ values of $\mathrm{Cr}(\mathrm{VI})$ were calculated using the following equation:

$C_{\text {DGT }}=\frac{M \Delta \mathrm{g}}{D A t}$

where $M$ is the mass of $\mathrm{Cr}(\mathrm{VI})$ accumulated on the binding gel, $\Delta \mathrm{g}$ is the diffusion gel thickness, $D$ is the diffusion coefficient of $\mathrm{Cr}(\mathrm{VI})$ for the deployment temperature, $A$ is the area of the exposure window of the DGT device, and $t$ the deployment time. The diffusion coefficient for $\mathrm{Cr}(\mathrm{VI})$ at $25^{\circ} \mathrm{C}$ is $8.82 \times 10^{-6} \mathrm{~cm}^{2} \mathrm{~s}^{-1}$ (Pan et al. 2015). The DGT measurements were carried out in triplicate.

Furthermore, DGT devices (window size, $2.54 \mathrm{~cm}^{2}$ ) with $0.8 \mathrm{~mm}$ APA diffusion layer and 0.6 mm NMDG binding layer (DGT Research, Lancaster, UK) were loaded with $200 \mathrm{~mL}$ solutions $\left(30 \mathrm{mg} \mathrm{Cr} \mathrm{L}^{-1}\right.$ ) of various water-soluble $\mathrm{Cr}$ (III) $\left(\mathrm{CrCl}_{3}\right)$ and $\mathrm{Cr}(\mathrm{VI})\left(\mathrm{NaCrO}_{4}, \mathrm{~K}_{2} \mathrm{CrO}_{4}, \mathrm{~K}_{2} \mathrm{CrO}_{7}\right)$ compounds. The DGT devices were deployed for $24 \mathrm{~h}$ at $25^{\circ} \mathrm{C}$ in constantly agitated solutions. After deployment, the binding layers of the DGT devices were washed with distilled water, dried at room temperature, and analyzed by $\mathrm{Cr} \mathrm{K}$-edge XANES spectroscopy (see below).

\section{Chromium references for $\mathrm{Cr}$ K-edge XANES spectroscopy}

The following compounds were used for the chromium Kedge XANES spectroscopy measurements: $\mathrm{CaCrO}_{4}$, $\mathrm{Cr}_{2}\left(\mathrm{SO}_{4}\right)_{3} \cdot \mathrm{H}_{2} \mathrm{O}, \mathrm{Cr}_{2} \mathrm{~S}_{3}$ (all ABCR, Karlsruhe, Germany), $\mathrm{CrPO}_{4} \cdot 4 \mathrm{H}_{2} \mathrm{O}$ (Alfa Aesar, Karlsruhe, Germany), $\mathrm{Cr}_{2} \mathrm{O}_{3}$, $\mathrm{CrCl}_{3} \cdot 6 \mathrm{H}_{2} \mathrm{O}, \mathrm{K}_{2} \mathrm{Cr}_{2} \mathrm{O}_{7}$ (all Merck, Darmstadt, Germany), $\mathrm{K}_{2} \mathrm{CrO}_{4}$ (AppliChem, Darmstadt, Germany), and $\mathrm{Na}_{2} \mathrm{CrO}_{4}$ (Acros, Geel, Belgium). $\mathrm{Cr}(\mathrm{OH})_{3}$ was precipitated from an aqueous solution of chromium chloride $\left(\mathrm{CrCl}_{3}\right.$; p.a., SigmaAldrich, Australia) with ammonia. $\mathrm{CaCr}_{2} \mathrm{O}_{4}, \mathrm{MgCr}_{2} \mathrm{O}_{4}$, and $\mathrm{FeCr}_{2} \mathrm{O}_{4}$ were prepared from $\mathrm{Cr}_{2} \mathrm{O}_{3}$ (p.a., Merck, Darmstadt, Germany) with calcium carbonate $\left(\mathrm{CaCO}_{3}\right.$; Sigma-Aldrich,
Steinheim, Germany), magnesium carbonate $\left(\mathrm{MgCO}_{3}\right.$; Merck, Darmstadt, Germany), and $\mathrm{Fe}_{3} \mathrm{O}_{4}$ (ABCR, Karlsruhe, Germany) at $1250{ }^{\circ} \mathrm{C}, 1000^{\circ} \mathrm{C}$, and $1500^{\circ} \mathrm{C}$, respectively, in platinum crucibles by thermal treatment (6$16 \mathrm{~h}$ ) in a muffle furnace (Nabertherm LH 15/14, Lillenthal, Germany). Cr-substituted $\mathrm{FeOOH}$ was prepared after Frommer et al. (2009).

\section{Chromium K-edge XANES spectroscopy of fertilizers}

Chromium K-edge XANES spectroscopy measurements were carried out at P64 beamline (Caliebe et al. 2019) at the electron storage ring PETRAIII (DESY, Hamburg, Germany). The incident beam was monochromatized with a $\mathrm{Si}<111>$ double crystal monochromator. The scans were acquired at $50 \mathrm{~K}$, to reduce radiation damage in the sample. The $\mathrm{Cr}$ K-edge XANES spectra were collected in the range of $5980-6100 \mathrm{eV}$ with a Canberra 100 pixel high-purity germanium detector in fluorescence mode for the fertilizer samples. The $\mathrm{Cr}$ references were measured in transmission mode using two ion chambers filled with nitrogen. All spectra were background subtracted and normalized to an edge jump of $\Delta \mu \mathrm{d}=1$.

Afterwards, Cr K-edge XANES spectra of the fertilizers were fitted with linear combination fitting (LCF) of Cr reference compounds (following mentioned as XANES-LCF) with the software Demeter Athena (Ravel and Newville 2005). Therefore, the following XANES spectra were used: $\mathrm{CaCrO}_{4}, \mathrm{Na}_{2} \mathrm{CrO}_{4}, \mathrm{~K}_{2} \mathrm{CrO}_{4}, \mathrm{~K}_{2} \mathrm{Cr}_{2} \mathrm{O}_{7}, \mathrm{Cr}_{2} \mathrm{O}_{3}, \mathrm{MgCr}_{2} \mathrm{O}_{4}$, $\mathrm{CaCr}_{2} \mathrm{O}_{4}, \mathrm{FeCr}_{2} \mathrm{O}_{4}, \mathrm{CrCl}_{3}, \mathrm{Cr}(\mathrm{OH})_{3}, \mathrm{CrPO}_{4}$, and Cr-sub. $\mathrm{FeOOH}$. The relative proportions of the components, whose number was limited to three, were forced to add up to $100 \%$. From the remaining fits, the best fit was chosen, as seen by the highest $R$ value.

A second method, in the following named XANES-H, was applied to calculate the $\mathrm{Cr}(\mathrm{VI})$ amounts from the XANES spectra for comparison. Here, the height of the pre-peak was analyzed in relation to the height of the edge:

XANES-H $=\frac{\text { Height pre-peak }(5992.8 \mathrm{eV})-\text { Height baseline }(5990 \mathrm{eV})}{\text { Height edge }(6009 \mathrm{eV})-\text { Height baseline }(5990 \mathrm{eV})}$

The values from the reference spectra of $\mathrm{Cr}_{2} \mathrm{O}_{3}$ and $\mathrm{CaCrO}_{4}$ were set to $0 \%$ and $100 \% \mathrm{Cr}(\mathrm{VI})$, respectively.

\section{Results and discussion}

\section{Chromium and $\mathrm{Cr}(\mathrm{VI})$ contents of the investigated fertilizers}

In Table 1, the amounts of total $\mathrm{Cr}$ and $\mathrm{Cr}(\mathrm{VI})$ are listed for the different P-fertilizers. For $\mathrm{Cr}(\mathrm{VI})$, the data of the different investigated methods are given, respectively. For the series 
Table 1 Total Cr mass fraction and $\mathrm{Cr}(\mathrm{VI})$ amount (with standard deviation) analyzed with the wet chemical extraction (DIN), DGT, and Cr K-edge XANES spectroscopy (number in brackets is ratio $\mathrm{Cr}(\mathrm{VI}) /$ total $\mathrm{Cr}$ ) method, respectively, for various fertilizers

\begin{tabular}{llllll}
\hline & Total Cr & \multicolumn{2}{l}{ Cr(VI) } & & \\
\cline { 3 - 6 } & & DIN & DGT & $\begin{array}{l}\text { XANES- } \\
\text { LCF }\end{array}$ & XANES-H \\
\hline & & & & $\mathrm{mg} / \mathrm{kg}$ & $\mathrm{mg} / \mathrm{kg}$ \\
SSA & $118.3 \pm 4.6$ & $0.1 \pm 0.1(0 \%)$ & $0.3 \pm 0.1$ & $\mathrm{bql}$ & $\mathrm{bql}$ \\
SSA-Na1 & $113.9 \pm 1.3$ & $0.1 \pm 0.1(0 \%)$ & $0.2 \pm 0.1$ & $\mathrm{bql}$ & $\mathrm{bql}$ \\
SSA-Na2 & $110.6 \pm 3.7$ & $0.1 \pm 0.1(0 \%)$ & $\mathrm{bql}$ & $\mathrm{bql}$ & $\mathrm{bql}$ \\
SSA-Na3 & $102.3 \pm 2.2$ & $0.2 \pm 0.1(0.2 \%)$ & $14.3 \pm 1.2$ & $\mathrm{bql}$ & $0.8(0.8 \%)$ \\
SSA-Na4 & $98.1 \pm 0.4$ & $8.1 \pm 0.1(8 \%)$ & $84.2 \pm 1.5$ & $11.1(11 \%)$ & $6.8(7 \%)$ \\
SSA-Na5 & $95.1 \pm 1.5$ & $12.3 \pm 0.2(13 \%)$ & $110.2 \pm 2.2$ & $19.3(20 \%)$ & $10.0(11 \%)$ \\
SSA-Na6 & $86.9 \pm 6.1$ & $68.5 \pm 0.2(78 \%)$ & $276.5 \pm 3.6$ & $50.8(58 \%)$ & $36.7(42 \%)$ \\
PR & $177.0 \pm 2.1$ & $0.7 \pm 0.2(0.4 \%)$ & $11.2 \pm 2.1$ & bql & bql \\
TSP & $77.6 \pm 1.4$ & $0.5 \pm 0.1(0.6 \%)$ & $36.6 \pm 2.8$ & bql & bql \\
CL & $1168.5 \pm 13.6$ & $7.4 \pm 0.2(0.6 \%)$ & $7.6 \pm 1.1$ & bql & bql \\
\hline
\end{tabular}

$b q l$ below quantification limit, $P R$ phosphate rock, TSP triple superphosphate, $C L$ converter lime of thermochemically treated SSA (SSA, SSA-Na1 - SSA$\mathrm{Na6}$ ), it can be clearly seen that the total $\mathrm{Cr}$ content decreases from 118.3 (SSA) to $86.9 \mathrm{mg} / \mathrm{kg}$ (SSA-Na6) due to the dilution with increasing amounts of added $\mathrm{Na}_{2} \mathrm{CO}_{3}$. At the same time, the formation of $\mathrm{Cr}(\mathrm{VI})$ is clearly initiated by thermochemical reaction with the $\mathrm{Na}$ additive and oxygen starting from $0.2 \mathrm{Cr}(\mathrm{VI})$ in SSA-Na3 and increasing to $68.5 \mathrm{mg} / \mathrm{kg}$ $\mathrm{Cr}(\mathrm{VI})$ present in SSA-Na6 (data of DIN method) (see also Fig. S1). A thermochemical treatment according to recipe SSA-Na4 would lead to $\mathrm{Cr}(\mathrm{VI})$ mass fractions above the limit of $2 \mathrm{mg} / \mathrm{kg}$ of the German Fertilizer Ordinance. The tested TSP and the PR have both $\mathrm{Cr}(\mathrm{VI})$ mass fractions below the limit of $2 \mathrm{mg} / \mathrm{kg}$ (DIN method). The converter lime CL showed with $7.4 \mathrm{mg} / \mathrm{kg} \mathrm{Cr}(\mathrm{VI})$ a value above the limit for fertilizers in Germany (DIN method).

\section{Applicability of the DGT method for the determination of $\mathrm{Cr}(\mathrm{VI})$ in P-fertilizers}

The DGT method adsorbs mobile Cr(VI) from the fertilizer/ water mixture for a certain definite time span and is thus not an absolute method. The data from DGT are given in $\mu \mathrm{g} \mathrm{L}^{-1}$ after extraction of the DGT binding layer following a defined procedure (see "Materials and methods" section). Thus, a calibration with standard materials would be required to determine $\mathrm{Cr}(\mathrm{VI})$ mass fractions by DGT which was not part of this work. However, we found a good correlation $\left(R^{2}=0.93\right)$ between the wet chemical extraction (DIN method) and the data determined by the DGT method for the series of ash-based model fertilizers SSA - SSA-Na6 (see Fig. S2).

However, the conventional fertilizers TSP and CL show no correlation between DIN and DGT results (see red and green circle, respectively, in Fig. 1). The CL fertilizer contains a very high mass fraction of $\mathrm{CaO}(>40 \%)$ which could support the development of $\mathrm{CaCrO}_{4}$ (Vogel et al. 2015b). This $\mathrm{Cr}(\mathrm{VI})$ compound is, in contrast to the other $\mathrm{Cr}(\mathrm{VI})$ compounds, only hardly water-soluble (Vogel et al. 2014) which might be the reason for the low DGT value. In contrast, TSP has a much higher DGT value compared with wet chemical extraction. TSP is made from phosphate rock which is treated with phosphoric acid during production. Here, a formation of mobile $\mathrm{Cr}$ (III) species could be possible. In fact, Pan et al. (2015) stated that small amounts of $\mathrm{Cr}$ (III) can also be adsorbed to the DGT binding layer. Thus, to determine the $\mathrm{Cr}(\mathrm{VI})$ selectivity and robustness of the DGT method, the investigated P-

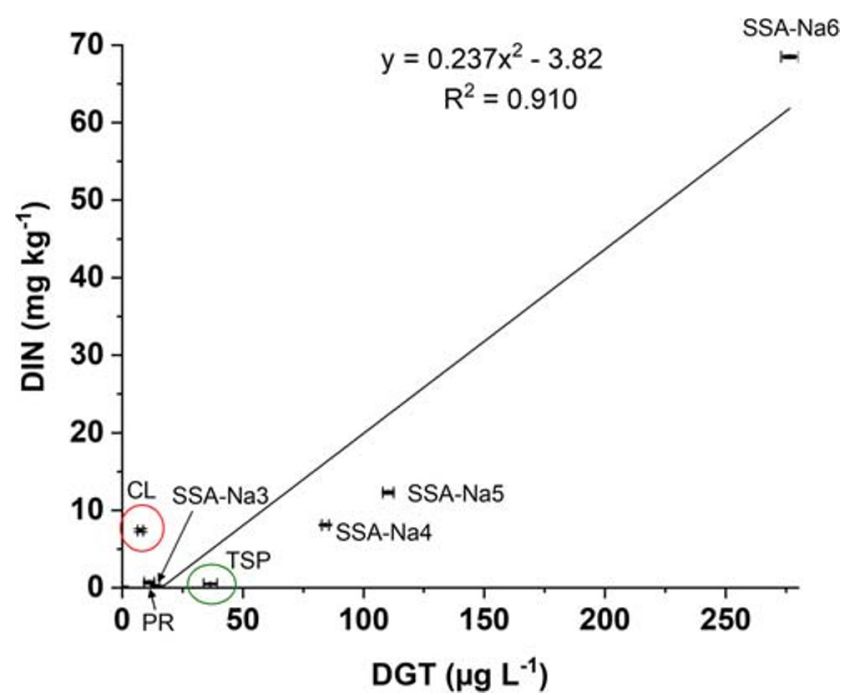

Fig. 1 Comparison of $\mathrm{Cr}(\mathrm{VI})$ mass fractions in fertilizers between DIN (wet chemical) method and DGT method (values with standard deviation). The red circle shows CL, and the green circle shows TSP. The points of the fertilizers SSA to SSA-Na2 are at the zero intersection 
fertilizers and their DGT binding layers were analyzed by $\mathrm{Cr}$ K-edge XANES spectroscopy after deployment.

\section{Comparison between DGT method and XANES spectroscopy}

Figure 2 shows the Cr K-edge XANES spectra of various Pfertilizers. All spectra have a white line at $6008 \mathrm{eV}$ and a postedge feature at $6023 \mathrm{eV}$ (except for SSA-Na6). These features come close to those of $\mathrm{Cr}$ (III) reference compounds presented in Fig. 3. The fertilizers SSA-Na4, SSA-Na5, and SSA-Na6 show an additional pre-peak of $\mathrm{Cr}(\mathrm{VI})$ at $5992 \mathrm{eV}$. Linear combination fitting (LCF) of SSA (Fig. 4 top) indicates mainly chromite $\left(\mathrm{MgCr}_{2} \mathrm{O}_{4}\right.$ or $\left.\mathrm{FeCr}_{2} \mathrm{O}_{4}\right)$ and chromium phosphate as Cr-bearing phases. Very similar results were also detected for the materials SSA-Na1 to SSA-Na3. In contrast, the LCF fit of SSA-Na6 (Fig. 4 bottom) also indicates $\mathrm{Cr}(\mathrm{VI})$ compounds in the fertilizer. A similar result was found for SSANa4 and SSA-Na5. From the results of the LCF fits and the total mass fractions of $\mathrm{Cr}$ (Table 1) in the fertilizers, the $\mathrm{Cr}(\mathrm{VI})$
Fig. 2 Chromium K-edge XANES spectra of various fertilizers

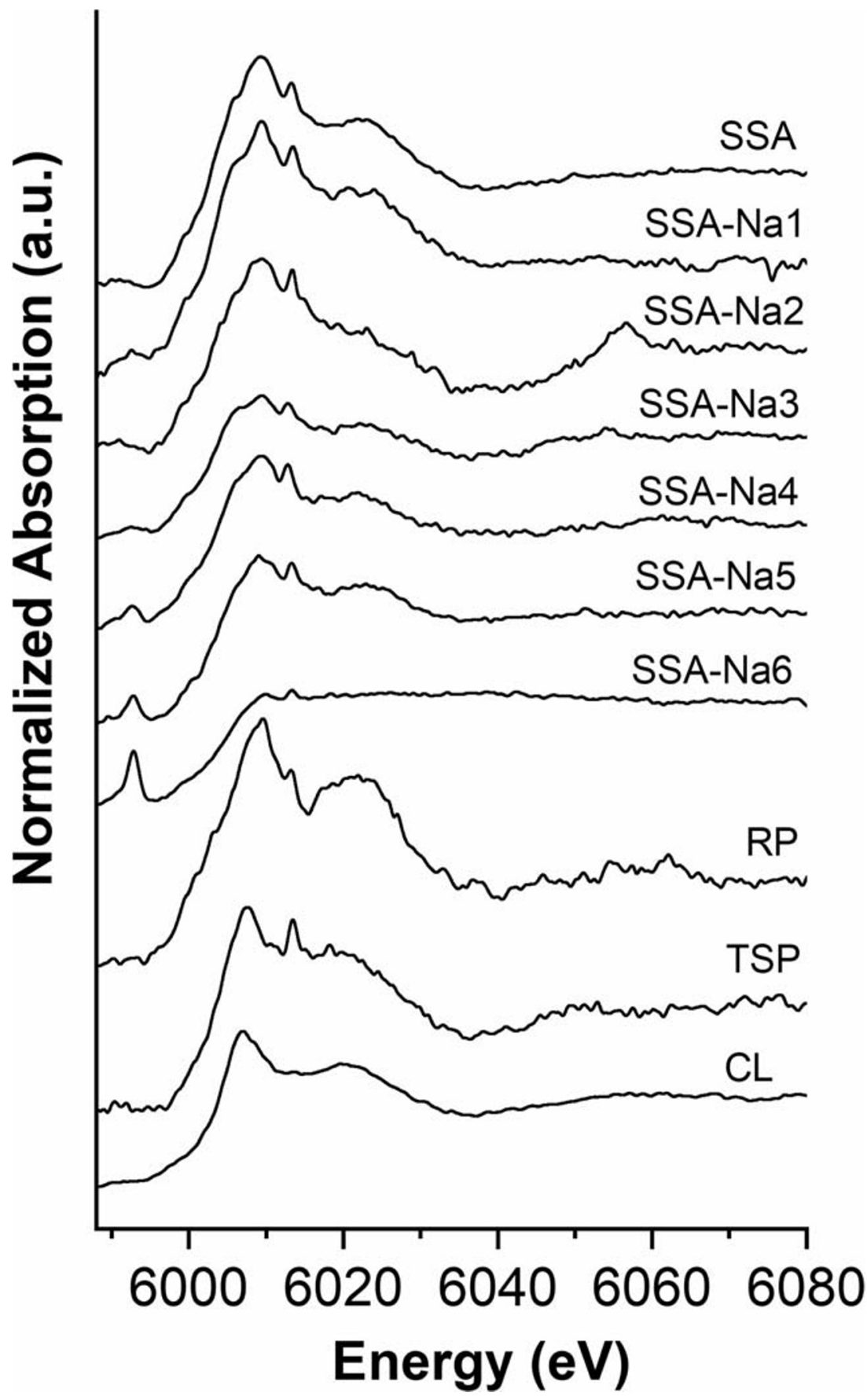


Fig. 3 Chromium K-edge XANES spectra of various $\mathrm{Cr}$ compounds



amount was calculated (see XANES-LCF in Table 1). In contrast to the LCF of the XANES spectra (XANES-LCF), the DGT and wet chemical $\mathrm{Cr}(\mathrm{VI})$ analyses indicate also $\mathrm{Cr}(\mathrm{VI})$ in SSA-Na3, PR, TSP, and CL (Table 1). Only the results from the SSA-based materials with higher $\mathrm{Cr}(\mathrm{VI})$-contents show a good correlation to the DGT method $\left(R^{2}=0.99\right.$; Fig. S3).
In contrast to the XANES-LCF approach, the XANES-H approach indicates $\mathrm{Cr}(\mathrm{VI})$ in SSA-Na3 to SSA-Na6 as it was observed by DGT and the wet chemical DIN method. Similarly to the XANES-LCF method, there is a good correlation between the XANES-H and DGT method for SSAbased fertilizers $\left(R^{2}=0.97\right.$; Fig. S4) and an even better 
Fig. 4 Chromium K-edge XANES spectrum of SSA (top) and SSA-Na6 (bottom) and corresponding linear combination fittings of different $\mathrm{Cr}$ references

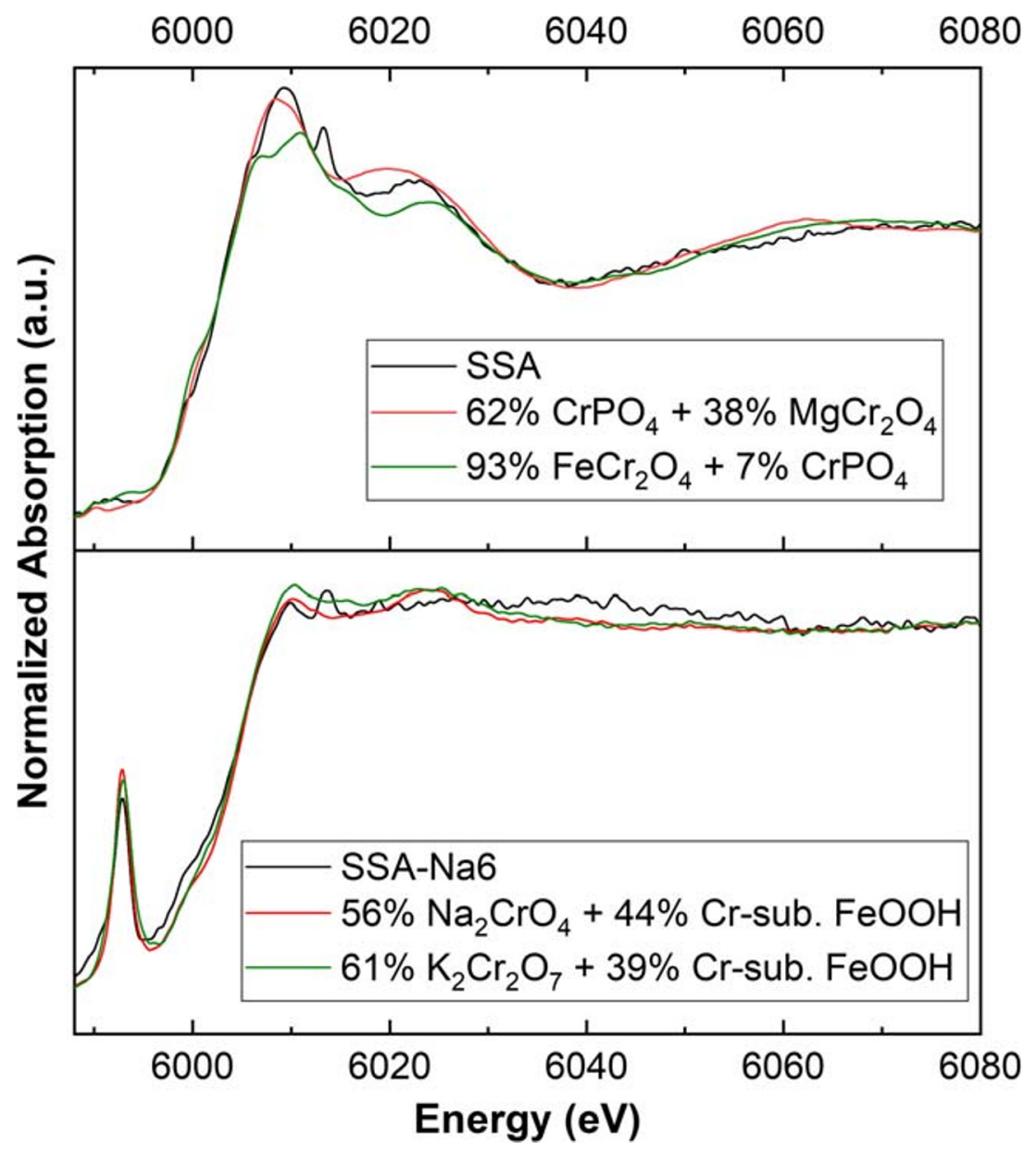

agreement for SSA-Na3. For the RP, TSP, and CL fertilizers, there is no agreement between DGT, wet chemical, and XANES-H method, since the latter indicates no $\mathrm{Cr}(\mathrm{VI})$ in these samples. Similarly to our approach, Bajt et al. (1993) and Rinehart et al. (1997) used a method where the area of the pre-peak was calculated. These authors revealed that fractions of $5 \%$ and $3 \% \mathrm{Cr}(\mathrm{VI})$ out of total $\mathrm{Cr}$ could barely be detected by $\mathrm{Cr} \mathrm{K}$-edge XANES spectroscopy, respectively. It is therefore likely to assume that a fraction of $3 \% \mathrm{Cr}(\mathrm{VI})$ out of total $\mathrm{Cr}$ represents the quantification limit for this technique. However, this XANES Cr(VI) quantification limit is independent from the total $\mathrm{Cr}$ amount. RP, TSP, and CL contain only 0.4-0.6\% $\mathrm{Cr}(\mathrm{VI})$ in relation to total $\mathrm{Cr}$ (according to DIN method; Table 1) and thus much less than the proposed quantification limit. Accordingly, these samples could be below the quantification limit of Cr K-edge XANES spectroscopy. In contrast, SSA-Na3 has only a $\mathrm{Cr}(\mathrm{VI})$ amount of $0.2 \%$ in relation to total $\mathrm{Cr}$ (DIN method, Table 1), but with the XANES-H method, a little bit higher amount $(0.8 \%$, Table 1$)$ could be detected. Thus, there might be a possibility that a quantification with the XANES-H method might be possible down to approx. $1 \% \mathrm{Cr}(\mathrm{VI})$ in relation to total $\mathrm{Cr}$.

\section{XANES spectroscopy investigations of deployed DGT binding layers}

Figure 5 (top) shows the Cr K-edge XANES spectra of the $\mathrm{Cr}(\mathrm{VI})$ selective DGT binding layers saturated with various $\mathrm{Cr}(\mathrm{III})$ and $\mathrm{Cr}(\mathrm{VI})$ compounds. The XANES spectra of the $\mathrm{Cr}(\mathrm{VI})$ saturated binding layers (top) are very similar to those of solid $\mathrm{Cr}(\mathrm{VI})$ compounds (see Fig. 3) and also show the characteristic pre-peak. In contrast, the $\mathrm{Cr}$ (III) saturated binding layer (DGT$\mathrm{CrCl}_{3}$ ) has no pre-peak, and the XANES spectrum features are close to those of solid chromites (see Fig. 3).

Due to the very low amounts of adsorbed $\mathrm{Cr}$ on the DGT binding layer, it was not possible to collect $\mathrm{Cr} \mathrm{K}$-edge XANES spectra for all deployed binding layers of the various fertilizers. SSA-Na4 and SSA-Na6 (SSA-Na5 was not investigated) show the $\mathrm{Cr}(\mathrm{VI})$ pre-peak, and the spectra come close to those of the $\mathrm{Cr}(\mathrm{VI})$ DGT references. Due to the high signal-to-noise ratio of the XANES spectrum of SSA-Na3, a detection of a Cr(VI) pre-peak was impossible (see Fig. 5). In contrast to SSA-Na4 and SSA-Na6, the XANES spectrum of the deployed binding layer of TSP 
Fig. 5 Chromium K-edge XANES spectra of various deployed DGT binding layers

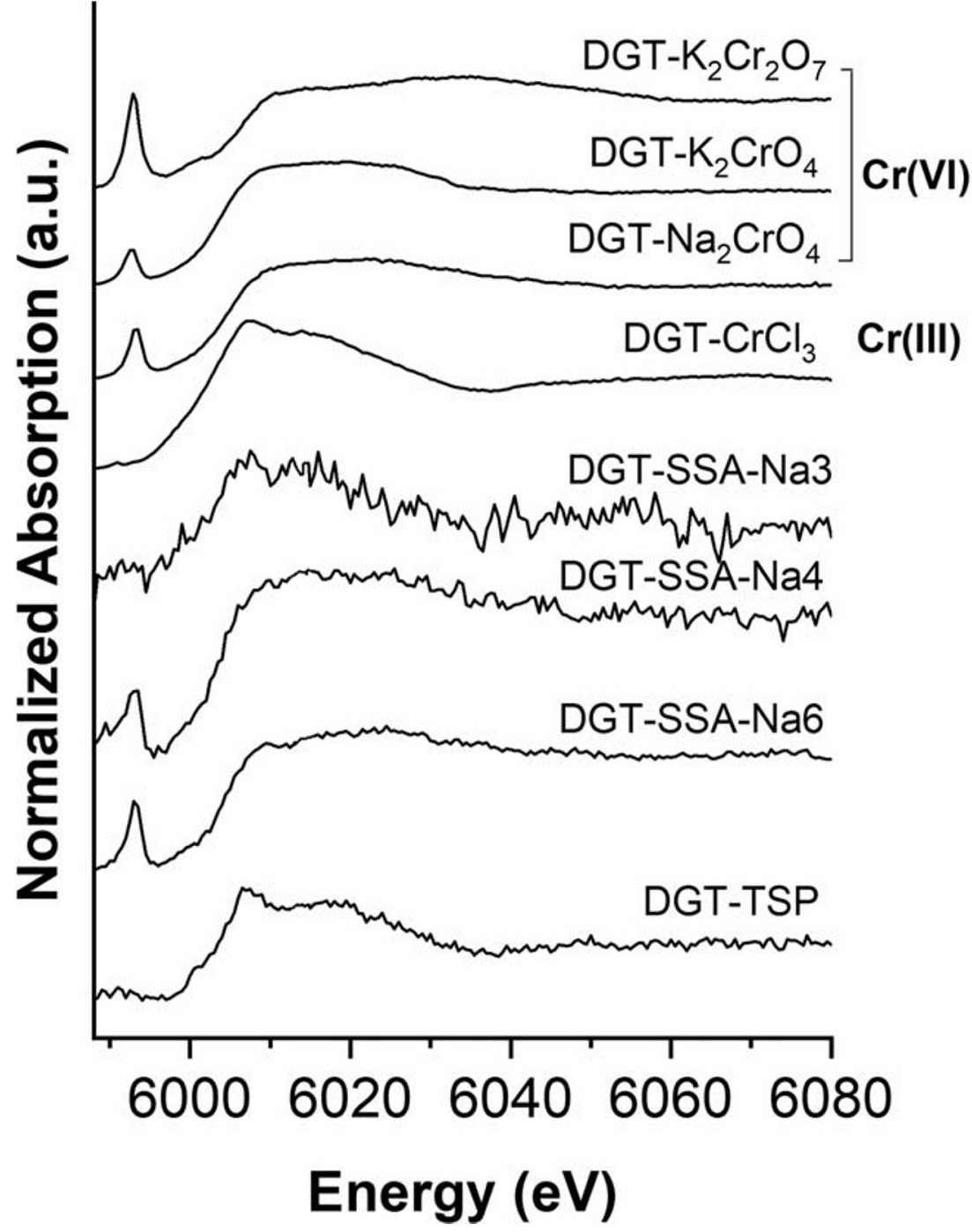

did not show a pre-peak. Furthermore, this XANES spectrum is also very similar to that of the DGT-Cr(III) reference. Therefore, we assume that TSP contains mobile Cr(III) that adsorbs also on the $\mathrm{Cr}(\mathrm{VI})$ selective binding layer. Thus, the existence of mobile $\mathrm{Cr}(\mathrm{III})$, which probably develops during the production of TSP, where phosphate rock is treated with phosphoric acid, might lead to an overestimation of $\mathrm{Cr}(\mathrm{VI})$ with the DGT method.

\section{Conclusion}

All three investigated methods for the determination of $\mathrm{Cr}(\mathrm{VI})$ in P-fertilizers from secondary or primary raw materials seem to have advantages and drawbacks. Krüger et al. (2017) mentioned earlier that the presence of organic matter and inorganic substances with potential to reduce $\mathrm{Cr}(\mathrm{VI})$ during wet chemical extraction according to the DIN method can cause underestimation of $\mathrm{Cr}(\mathrm{VI})$ in P-fertilizers. The DGT method was very sensitive and for most tested materials selective for the analysis of $\mathrm{Cr}$ (VI) in P-fertilizers made from recycled materials. However, the results of certain types of P-fertilizers containing mobile $\mathrm{Cr}(\mathrm{III})$ or hardly soluble $\mathrm{Cr}(\mathrm{VI})$ show that some optimization of the method is still required to avoid over- or underestimation of $\mathrm{Cr}(\mathrm{VI})$. Therefore, the DGT binding layer should be optimized so that mobile $\mathrm{Cr}$ (III) (like from fertilizer TSP) will no longer be adsorbed. Furthermore, the DGT method cannot detect hardly soluble Cr(VI). This, however, is also an advantage of this method because only the mobile and bioavailable $\mathrm{Cr}(\mathrm{VI})$, which is an important parameter for plant growth, will be analyzed. Additionally, the $\mathrm{Cr} \mathrm{K}$ edge XANES spectroscopy method also shows good results but fails to determine small amounts of $\mathrm{Cr}(\mathrm{VI})$ (below approx. $1 \% \mathrm{Cr}(\mathrm{VI})$ in relation to total $\mathrm{Cr}$ ) in fertilizers.

Acknowledgments Open Access funding provided by Projekt DEAL. We acknowledge DESY (Hamburg, Germany), a member of the Helmholtz Association HGF, for the provision of experimental facilities. Parts of this research were carried out on P64 beamline at PETRAIII. 
Funding information CV thanks the German Research Foundation (VO 1794/4-1) for financial support. VM thanks the German Federal Ministry for Education and Research (05K16PX1) for financial support.

Open Access This article is licensed under a Creative Commons Attribution 4.0 International License, which permits use, sharing, adaptation, distribution and reproduction in any medium or format, as long as you give appropriate credit to the original author(s) and the source, provide a link to the Creative Commons licence, and indicate if changes were made. The images or other third party material in this article are included in the article's Creative Commons licence, unless indicated otherwise in a credit line to the material. If material is not included in the article's Creative Commons licence and your intended use is not permitted by statutory regulation or exceeds the permitted use, you will need to obtain permission directly from the copyright holder. To view a copy of this licence, visit http://creativecommons.org/licenses/by/4.0/.

\section{References}

Bajt S, Clark SB, Sutton SR, Rivers ML, Smith JV (1993) Synchrotron $\mathrm{X}$-ray microprobe determination of chromate content using X-ray absorption near-edge structure. Anal Chem 65:1800-1804

Caliebe W, Murzin V, Kalinko A, Görlitz M (2019) High-flux XAFSbeamline P64 at PETRAIII. AIP Conf Proc 2054:060031

Davison W (2016) Diffusive gradients in thin-films for environmental measurements. Cambridge University Press, Cambridge

DIN EN 15192, (2006). Characterization of waste and soil - determination of $\mathrm{Cr}(\mathrm{VI})$ in solid material by alkaline digestion and ion chromatography with spectrometric detection

EU, (2017). Communication from the Commission to the European Parliament, the Council, the European economic and social committee and the committee of the regions on the 2017 list of Critical Raw Materials for the EU

Frommer J, Nachtegaal M, Czekaj I, Weng TC, Kretzmar R (2009) X-ray absorption and emission spectroscopy of CrIII (hydr)oxides Analysis of the K-pre-edge region. J Phys Chem A 113:12171-12178

German Fertiliser Ordinance, (2012). In German language: Verordnung über das Inverkehrbringen von Düngemitteln, Bodenhilfsstoffen, Kultursubstraten und Pflanzenhilfsmitteln (Düngemittelverordnung - DüMV) vom 05. Dezember 2012, (BGB1. I S. 2482), die zuletzt durch Artikel 1 der Verordnung vom 2. Oktober 2019 (BGB1 I S. 1414) geändert worden ist

Herzel H, Krüger O, Hermann L, Adam C (2016) Sewage sludge ash — a promising secondary phosphorus source for fertilizer production. Sci Total Environ 542:1136-1143
ISO 11268-2, (2012). Soil quality-effects of pollutants on earthwormspart 2: determination of effects on reproduction of Eisenia fetida/ Eisenia andrei; Annex C; International Organization for Standardization (ISO): Geneve, Switzerland

Kratz S, Vogel C, Adam C (2019) Agronomic performance of P recycling fertilizers and methods to predict it: a review. Nutr Cycl Agroecosyst 115(1):1-39

Krüger O, Fiedler F, Adam C, Vogel C, Senz R (2017) Determination of chromium (VI) in primary and secondary fertilizer and their respective precursors. Chemosphere 182:48-53

Pan Y, Guan DX, Zhao D, Luo J, Zhang H, Davison W, Ma LQ (2015) Novel speciation method based on diffusive gradients in thin-films for in situ measurement of $\mathrm{Cr}^{\mathrm{VI}}$ in aquatic systems. Environ Sci Technol 49:14267-14273

Ravel B, Newville M (2005) ATHENA, ARTEMIS, HEPHAESTUS: data analysis for X-ray absorption spectroscopy using IFEFFIT. J Synchrotron Radiat 12:537-541

Rinehart TL, Schulze DG, Bricka RM, Bajt A, Blatchley ER (1997) Chromium leaching vs. oxidation state for a contaminated solidified/stabilized soil. J Hazard Mater 52:213-221

Schaum C (2018) Phosphorus: polluter and resource of the future. IWA Publishing, London

Shahid M, Shamshad S, Rafiq M, Khalid S, Bibi I, Niazi NK, Dumat C, Rashid MI (2017) Chromium speciation, bioavailability, uptake, toxicity and detoxification in soil-plant system: a review. Chemosphere 178:513-533

Stemann J, Peplinski B, Adam C (2015) Thermochemical treatment of sewage sludge ash with sodium salt additives for phosphorus fertilizer production - analysis of underlying chemical reactions. Waste Manag 45:385-390

Vogel C, Adam C, Kappen P, Schiller T, Lipiec E, McNaughton D (2014) Chemical state of chromium in sewage sludge ash based phosphorus-fertilisers. Chemosphere 103:250-255

Vogel C, Stemann J, Holldack K, Sekine R, Lipiec E, Adam C (2015a) Thermal treatment of chromium(III) oxide with carbonates analyzed by far-infrared spectroscopy. Appl Spectrosc 69:1210-1214

Vogel C, Radtke M, Reinholz U, Schäfers F, Adam C (2015b) Chemical state of chromium, sulfur, and iron in sewage sludge ash based phosphorus fertilizers. ACS Sustain Chem Eng 3:2376-2380

Vogel C, Sekine R, Steckenmesser D, Lombi E, Steffens D, Adam C (2017) Phosphorus availability of sewage sludge-based fertilizers determined by the diffusive gradients in thin films (DGT) technique. J Plant Nutr Soil Sci 180:594-601

Publisher's note Springer Nature remains neutral with regard to jurisdictional claims in published maps and institutional affiliations. 